\title{
Suriyeli Ebeveynlerin İlkokulda Aile Katılımına İlişkin Görüşlerinin İncelenmesi
}

\author{
DOI: $10.26466 /$ opus. 838731 \\ $*$ \\ Songül Tümkaya* - Ersin Çopur** \\ * Prof. Dr., Çukurova Üni., Eğitim Fakültesi, Adana/Türkiye \\ E-Posta: stumkaya@cu.edu.tr \\ ORCID: 0000-0003-0140-4640 \\ ** Dr. Öğr., Çukurova Üniversitesi, Lisansüstü Eğt. Ens., Adana/Türkiye \\ E-Posta: e.copur33@hotmail.com \\ ORCID: 0000-0002-7403-9018
}

\section{Öz}

Çocukların daha kaliteli eğitim alması ve başarıya ulaşabilmesi, ailelerinin eğitime verdikleri önemle doğru orantılıdır. Bu gerçeklikten hareketle, yapılan bu çalışmada Türkiye'ye göç etmiş olan Suriyeli ailelerin ilkokulda aile katılımı hakkındaki görüşlerinin belirlenmesi amaçlanmıştır. Araştırmada nitel araştırma yaklaşımına dayalı olgubilim deseni kullanılmıştır. Araştırmanın çalı̧̧ma grubu Mersin İli Tarsus İlçesindeki ilkokullarda çocukları öğrenim görmekte olan 10 Suriyeli veliden (7 Suriyeli anne ve 3 Suriyeli baba) oluşmuştur. Verilerin çözümlenmesinde içerik analizinden yararlanılmıştır. Araştırmanın sonuçlarına göre Suriyeli ebeveynler, ailelerin eğitim sürecine katılımını bir ihtiyaç olarak görmektedirler fakat eğitimde aile katılımının önünde birtakım engeller olduğunu düşünmektedirler. Türkçe bilmemeleri, farklı kültüre sahip olmaları, ağır şartlar altında çalışmaları, maddi yetersizlikler, Suriyeli ailelerin eğitim sürecine katılımlarının önündeki engellerdendir. Araştırmaya katılan Suriyeli ebeveynlerin tamamı aile katılım çalışmalarında aktif olarak rol almalarının, kendilerine ve çocuklarına birtakım faydalar sağlayacağı yönünde ortak görüş bildirmişlerdir. Ayrica Suriyeli ebeveynlerin tümünün, eğitimde aile katılımında daha aktif olabilmek için Türk ebeveynlerden, öğretmenlerden ve okul idarecilerinden bazı beklentiler içinde olduklarl görülmüştür.

Anahtar Kelimeler: Aile, aile katılımı, ilkokul, Suriyeli aileler. 


\title{
Investigation of Syrian Parents' Views on Parental Involvement in Primary School
}

*

\begin{abstract}
The success of children by getting a higher quality education is directly proportional to the importance given to education by their families. Starting from this reality, this study was aimed to determining the views on parental involment in primary school of Syrian families who have migrated to Turkey. The phenomenon pattern based on qualitative research approach was used in the study. The study group of the study consisted of 10 Syrian parents (7 Syrian mothers and 3 Syrian fathers) whose children are studying at primary schools in Tarsus, Mersin. Content analysis was used to analyze the research data. According to the results of the study, Syrian parents see the involvement of parents in the education process as a need, but they think that there are some obstacles to parental involvement in education. Not speaking Turkish, having a different culture, working under heavy conditions, financial inadequacies are among the obstacles to the involvement of Syrian families in the education process. According to all of the Syrian parents participating in the research, being active in family participation activities provides them and their children with certain benefits. In addition, it was concluded that all Syrian parents had certain expectations from Turkish parents, teachers and school administrators in order to be more active in parental involvement in education.
\end{abstract}

Keywords: Family, family participation, primary school, Syrian families. 


\section{Giriş}

Öğrencilerin akademik başarılarını, davranışlarını ve başkalarıyla iletişim süreçlerini etkileyen birçok faktör vardır. Aile, akla ilk gelen faktörlerden biridir. Ebeveynlerin çocuklarının başarısına katkı sunabilmek ve onların daha kaliteli bir eğitim-öğretim ortamında hayata hazırlanmalarını sağlamak için öncelikle kendi çocuklarını her yönüyle tanımaları gerekmektedir. Çocuğunu yeteri kadar tanımayan, onun davranış hakkında fikir sahibi olmayan, ilgi ve ihtiyaçlarından haberdar olmayan ebeveynlerin, çocuklarının hayata hazırlaması noktasında başarılı oldukları söylenemez (Aslanargun, 2007).

Aile ve okul, çocukların yeni bir şeyler öğrendikleri, kendilerini geliştirebildikleri, etkileşim kurarak kazanım elde ettikleri kurumlardır. Eğitimciler, siyasetçiler ve araştırmacılar okul ve aile işbirliğini, öğrenci başarısı açısından önemli görmektedirler (Simon, 2004). Bu nedenle, araştırmacılar son yıllarda okul aile işbirliğini temel alan birçok araştırma yapmakta ve yaptıkları araştırmalarda, çocukların okul başarısında ailelerin yani ebeveynlerin rolüne yönelmektedirler (Rogers, Theule, Ryan, Adams ve Keating, 2009; Dam, 2009; Alkan, 2018). Yapılan bu araştırmalar iki türde gerçekleştirilmektedir (Ryan ve Adams, 1999). Birinci tür, ebeveyn-öğretmen iletişimi ve okul komitelerine veli katılımı gibi ebeveynlerin bir kurum olarak okula katılımı (Dearing, Kreider, Simpkins ve Weiss, 2006; Hill ve Taylor, 2004; Tümkaya, 2017), ikinci tür ise özellikle ev ödevlerine yardımcı olmak gibi çocukların akademik gelişimiyle ilgili olan evdeki ebeveynlik davranışlarının araştırılmasını içerir (Hoover Dempsey ve diğ., 2001; Zeith , Reimers, Fehrmann, Pottebaum ve Aubey, 1986).

Okul, gelecekteki emek ve sosyal katılıma açılan kapıdır. Eğitim, öğrencileri kariyer, özel hayat ve topluma katılım açısından geleceğe hazırlar. Geleceğe dair kazanımların elde edilmesinde okul ve aile işbirliği büyük önem taşımaktadır. Ebeveynlerin eğitime katılımı, daha yüksek akademik başarı (Hoover Dempsey ve diğ., 2001; Seginer, 2006; Keçeli Kaysıl1, 2008; Argon ve Kıyıc1, 2012) okula karşı daha olumlu tutum geliştirme (Çelenk, 2003; Gonzalez-DeHass, Willems ve Holbein, 2005; Mafa ve Makuba, 2013), gelecek yaşantılarına katkı sunma (Epstein, 2002) 
dâhil olmak üzere çeşitli şekillerde çocuklara olumlu sonuçlar sağlamaktadır.

Epstein (1995) ailelerin eğitim sürecine nasıl katılabileceğini ve ne tür etkinliklerin uygulanabileceğini gösteren kategoriler oluşturmuştur. Oluşturulan kategoriler, "Çocuk bakımı", "İletişim”, “Gönüllülük”, "Evde Öğrenme", "Karar Verme" ve "Toplumla İşbirliği"dir (Akt.,Tümkaya, 2017).

Epstein (1995) tarafından oluşturulmuş olan kategoriler uyguland1ğında ailelerin okula karşı olumlu tutum geliştirmeleri sağlanabilir. Ailelerin okul ve öğretmenlere ilişkin tutumları olumlu olduğunda, öğrenciler de kendilerinden beklenen olumlu davranışları göstermektedirler. Ailenin eğitime katılımı, aile ve öğretmenlerin eğitime dair konularda birbirlerini tanımalarına ve bu konuda ortak hareket sergilemelerine katkı sağlamaktadır.

Tarihsel süreçler incelendiğinde, bazen insanların yaşadıkları bölgeleri terk etmek zorunda kalarak göç ettikleri görülmektedir. Bu göçlere genellikle ekonomik sebepler, eğitim ihtiyacı ve ideolojik düşünceler (Taşkaya, 2016) yol açmakta fakat insanları göçe zorlayan en önemli nedenin, göçmenlerin ülkelerinde yaşanan kargaşalar olduğu görülmektedir (Akkaya, 2013). Son yıllarda Ortadoğu coğrafyasında yaşanan kargaşalar, Türkiye'yi sürekli göç alan ülke konumuna getirmiştir. Suriye'de yaşanan iç savaş neticesinde, Suriyeliler 2011 yılından bu yana Türkiye'ye kitlesel olarak şekilde göç etmişlerdir (Demirtaş, 2019).

2020 yılı verilerine göre Türkiye'de, yaklaşık 3.6 milyon Suriye vatandaşı ve 330.000'e yakın kayıtlı mülteci ve diğer milletlerden sığınmacı yaşamaktadır. Suriyeli mültecilerin $\% 98$ 'inden fazlası, Türkiye genelinde 81 ilde yaşamını devam ettirmektedir (The UN Refugee Agency). İçişleri Bakanlığ1 Göç İdaresinin yayınladığı yaş aralığı tablosuna göre; 10 yaşın altındaki Suriyelilerin sayısı 1 milyon 45 bin 617 kişidir ve 10 yaş altındaki çocukların toplam Suriyeli nüfusuna oranı ise \%28,8' dir (Mülteciler Derneği).

Çocukların gelecek yaşantılarının oluşmasında, okul ve aile büyük öneme sahiptir. Okulda ulaşılmak istenen hedeflere, ailenin desteği olmadan ulaşmak neredeyse imkansızdır. Hedeflere daha rahat ulaşmak adına izlenecek yollardan birisi, ailelerin okulda yapılanlar hakkında bilgilendirilmesidir (Tümkaya ve Çopur, 2020). Tüm bunlardan önce 
yapılması gereken şey ise Suriyeli ebeveynlerin eğitimde aile katılım çalışmalarına dair düşüncelerinin belirlenmesidir. Bu çalışma, Suriyeli ebeveynlerin ilkokulda aile katılımı hakkındaki görüşlerinin tespit edilmesi ve bu tespitler neticesinde Suriyeli ebeveynlerin aile katılım çalışmalarında daha aktif bir şekilde rol almasını sağlayacak etkinliklerin planlanmasında yol gösterici olabileceğinden ötürü önemlidir. Bu noktadan hareketle yapılan bu çalışmada, Suriyeli ebeveynlerin ilkokulda aile katılımına ilişkin görüşlerini belirlemek amaçlanmıştır. Bu amaç doğrultusunda aşağıdaki sorulara yanıt aranmıştır:

- Suriyeli ebeveynlerin aile katılımı çalışmalarına yönelik farkındalık durumları nasıldır?

- Suriyeli ebeveynlerin eğitim sürecine aktif katılımlarının, kendilerine ve çocuklarına sağladığı faydalara yönelik görüşleri nelerdir?

- Suriyeli ebeveynlerin aile katılım çalışmalarında karşılaştıkları sorunlara yönelik görüşleri nelerdir?

- Suriyeli ebeveynlerin aile katılım çalışmalarında Türk ebeveynlerden, sınıf öğretmenlerinden ve okul yönetimlerinden beklentilerine yönelik görüşleri nelerdir?

\section{Yöntem}

\section{Araştırma Modeli}

Bu çalışmada, Suriyeli ebeveynlerin ilkokulda ile katılımına ilişkin düşünceleri hakkında detaylı bilgi elde edebilmek amacıyla nitel araştırma yöntemlerinden olgubilim (fenomenoloji) deseni kullanılmıştır. Olgu biliminde katılımcıların olaylara, olgulara (fenomen) ve eylemlere hangi anlamları yükledikleri araştırılır. Bu yaklaşımda nasıl ve neden sorularına cevap aranır (Gliner, Morgan and Leech, 2015). Olgubilim çalışmalarının esas amacı, bir olguya dair kişisel deneyimlerin, daha genel bir düzeye çekilmesidir (Creswell, 2007). Tümüyle yabancı olunmayan ve tam olarak anlamının kavranamadı̆̆ı olguları araştırmak maksadıyla yapılan çalışmalar için olgubilim uygun bir araştırma zemini oluşturur (Yıldırım ve Şimşek, 2016). 


\section{Çalışma Grubu}

Araştırmanın çalışma grubu, çocukları Mersin İli Tarsus İlçesindeki ilkokullarda öğrenim görmekte olan 10 Suriyeli veliden (7 Suriyeli anne ve 3 Suriyeli baba) oluşmuştur. Çalışma grubu, amaca yönelik örnekleme desenlerinden kartopu örnekleme yöntemi kullanılarak oluşturulmuştur. Kartopu örnekleme yöntemi, katılımcılardan görüşme için başkalarını tavsiye etmesini isteyerek örneklemi genişletme yöntemidir (Babbie, 2010). Bu örnekleme yöntemi araştırmacının yanıt bulmak istediği problemle ilgili zengin bilgi kaynağı olabilecek kişi ya da durumların belirlenmesinde oldukça etkilidir (Yıldırım ve Şimşek, 2016). Bu çalışmada yer alan katılımcılar, ilkokulda aile katılımına ilişkin detaylı bilgiye sahip olabilecek Suriyeli ebeveynleri araştırmacılara önermiş ve görüşmeler katılımclar tarafından önerilmiş olan ebeveynlerle gerçekleştirilmiştir. Katılımcı bilgileri Tablo 1'de sunulmuştur.

\section{Tablo 1. Katılımcıların Bireysel Özelliklere Göre Dağılımı}

\begin{tabular}{llll}
\hline Değişkenler & $\mathbf{N}$ & $\mathbf{\%}$ \\
\hline \multirow{3}{*}{ Yaş } & $20-30$ yaş & 3 & 30 \\
& 31- 40 yaş & 3 & 30 \\
& $41-50$ yaş & 2 & 20 \\
\hline Cinsiyet & 51 yaş ve üzeri yaş & 2 & 20 \\
\hline \multirow{2}{*}{ Eğitim Durumu } & Kadın & 7 & 70 \\
& Erkek & 3 & 30 \\
\hline \multirow{3}{*}{ Çocuk Sayısı } & İlkokul & 3 & 30 \\
& Ortaokul & 0 & 0 \\
& Lise & 3 & 30 \\
& Lisans & 4 & 40 \\
\hline
\end{tabular}

Tablo 1 incelendiğinde, araştırmaya katılanların 3'ü (\%30) 20-30 yaş grubunda, 3'ü (\% 30) 31-40 yaş grubunda, 2'si (\%20) 41-50 yaş grubunda ve 2 'si (\% 20) 51 yaş ve üzeri yaş grubunda yer almaktadır. Katılımcıların 7'si (\%70) kadın ve 3'ü (\% 30) erkektir. Eğitim durumu açısından incelendiğinde, katılımclların 3'ü (\%30) ilkokul, 3'ü (\% 30) lise ve 4'ü (\% 40) lisans mezunudur. Çocuk sayısı bakımından incelendiğinde ise katı- 
lımcıların 3'ünün (\%30) 2 çocuk, 5'inin (\%50) 3 çocuk ve 2'sinin (\% 20) 4 çocuk sahibi oldukları görülmektedir.

\section{Veri Toplama Araci}

Araştırmada yarı yapılandırılmış görüşme formu kullanılmıştır. Görüşme formunun hazırlık aşamasında öncelikle literatür taranmış, 22 soruluk taslak form oluşturulmuş ve bu form uzman görüşüne sunulmuştur. Uzman değerlendirmeleri sonucunda formda gerekli düzeltmeler yapıldıktan sonra iki Suriyeli ebeveyn ile deneme görüşmesi yapılmıştır. Suriyeli ebeveynlerle yapılan deneme görüşmesi göz önünde bulundurularak sorulara son şekli verilmiştir. Son şekli verilen görüşme formunda Suriyeli ailelerin aile katılımına ilişkin farkındalık düzeyi, aile katılımının sağladığ faydalar, aile katılımında karşılaştıkları sorunlar ve beklentileri çerçevesinde oluşturulan 16 açık uçlu soru yer almıştır.

\section{Verilerin Toplanması}

Katılımcılarla görüşmeler, uygun olduklarını belirttikleri gün ve saatte, kendi evlerinde, tercümandan da destek alınarak gerçekleştirilmiştir. Katılımcılara isimlerinin herhangi bir yerde geçmeyeceği bildirilmiş ve ses kaydı için katılımcılardan izin almıştır. Yapılan görüşmelerde akıllı telefon kullanılarak ses kaydı yapılmıştır. Görüşmelerin süresi 40 ila 55 dakika arasında değişmiştir. Daha sonra ise ses kaydı alınan görüşmelerin transkriptleri oluşturulmuş ve her bir transkript dosyasına kod etiketleri kadınlar için $\mathrm{K} 1 \ldots \mathrm{K} 7$, erkekler için E1...E3 şeklinde verilmiştir.

\section{Verilerin Analizi}

Araştırmadan elde edilen verilerin çözümlenmesinde, nitel veri analiz yöntemlerinden biri olan içerik analizinden yararlanılmış ve elde edilmiş olan bulgular yorumlanmıştır. İçerik analizinde temel amaç, toplanan verileri açıklayabilecek kavramlar ve ilişkilere ulaşmaktır. Toplanan verilerin önce kavramsallaştırılması, sonrasında ise ortaya çıkan kavramlara göre mantıklı bir biçimde düzenlenmesi ve buna göre veriyi açılayan temaların saptanması gerekir. İçerik analizinde temelde yapılan işlem, 
birbirine benzeyen verileri belirli kavramlar ve temalar çerçevesinde bir araya getirmek ve bunları okuyucunun anlayacağı bir biçimde düzenleyerek yorumlamaktır (Yıldırım ve Şimşek 2016). Yapılan bu çalışmada Yıldırım ve Şimşek'in (2016) belirttiği şekilde ilk aşamada veriler kodlanmış, ikinci aşamada temalar oluşturulmuş, üçüncü aşamada kodlar ve temalar düzenlenmiş ve dördüncü aşamada ise bulgular tanımlanmış ve yorumlanmıştır. Araştırmanın güvenirliğini arttırmak için katılımcıların görüşleri alıntılanarak sunulmuştur.

\section{Bulgular}

Bulgular, yapılan içerik analizi sonucunda elde edilen temalara göre "Suriyeli Ebeveynlerin Aile Katılımı Çalışmalarına Yönelik Farkındalıkları", "Suriyeli Ebeveynlere Göre Aile Katılımı Çalışmalarının Faydaları", "Suriyeli Ebeveynlerin Aile Katılımı Çalışmalarında Karşılaştıkları Sorunlar" ve "Suriyeli Ebeveynlerin Aile Katılımı Çalışmalarına Yönelik Beklentileri" olmak üzere dört ana başlıkta verilmiştir.

\section{Suriyeli Ebeveynlerin Aile Katılımı Çalışmalarına Yönelik Farkında- likları}

Araştırmada "Suriyeli Ebeveynlerin Aile Katılımı Çalışmalarına Yönelik Farkındalıkları" teması çerçevesinde elde edilen kodlar, alt kodlar ve alt kodların tekrarlanma sıklığı Tablo 2'de verilmiştir.

Tablo 2 incelendiğinde bu tema altında "okulun önemi", "aile katılım çalışmalarının ne ifade ettiği" ve "öğrencinin eğitimine katılım biçimi" kodlarının elde edildiği görülmektedir. Suriyeli ebeveynler, eğitimin öğrencilerin gelecek yaşantılarını şekillendirdiği, okulun insani değerleri ve temel becerileri öğrencilere kazandırdığı, öğrencilerin çevrelerindeki diğer bireylerle ve canlılarla olan iletişimlerini güçlendirmesini sağladığ 1 gibi sebeplerle okulu önemli gördüklerini belirtmişlerdir. Araştırmaya katılan Suriyeli ebeveynlerin bu konudaki görüşleri ile ilgili örnekler aşağıda verilmiştir. 
Tablo 2. Suriyeli Ebeveynlerin Aile Katılımı Çalışmalarına Yönelik Farkındalıkları

\begin{tabular}{|c|c|c|c|}
\hline Tema & Kodlar & Alt Kodlar & $\begin{array}{l}\text { Alt Kodların } \\
\text { Tekrarlanma } \\
\text { Sıklığı }\end{array}$ \\
\hline \multirow{16}{*}{$\begin{array}{l}\text { Suriyeli Ebev- } \\
\text { eynlerin Aile } \\
\text { Katılımı Çalışma- } \\
\text { larına Yönelik } \\
\text { Farkındalıkları }\end{array}$} & \multirow{4}{*}{ Okulun Önemi } & $\begin{array}{l}\text { Ĕ̆itimin, gelecek yaşantıları } \\
\text { şekillendirmesi }\end{array}$ & 6 \\
\hline & & $\begin{array}{l}\text { İnsani değerleri kazandır- } \\
\text { ması }\end{array}$ & 3 \\
\hline & & $\begin{array}{l}\text { Temel becerileri kazandır- } \\
\text { ması }\end{array}$ & 2 \\
\hline & & $\begin{array}{l}\text { İnsanlarla ve diğer canlılarla } \\
\text { olan iletişimi güçlendirmesi }\end{array}$ & 1 \\
\hline & \multirow{4}{*}{$\begin{array}{l}\text { Aile Katılımı Çalışma- } \\
\text { larının Ne İfade Ettiği }\end{array}$} & $\begin{array}{l}\text { Okuldaki başarıyı arttırmak } \\
\text { için yapılan çalışmalardır }\end{array}$ & 5 \\
\hline & & $\begin{array}{l}\text { Olumlu davranış kazan- } \\
\text { dırmak için yapılan çalışma- } \\
\text { lardır }\end{array}$ & 4 \\
\hline & & $\begin{array}{l}\text { Çocuğun hayata hazır- } \\
\text { lanması için yapılan } \\
\text { çalışmalardır }\end{array}$ & 1 \\
\hline & & $\begin{array}{l}\text { Okulda başlayan sürecin } \\
\text { evde de devam etmesi için } \\
\text { yapılan çalışmalardır }\end{array}$ & 2 \\
\hline & \multirow{8}{*}{$\begin{array}{l}\text { Öğrencinin Eğitimine } \\
\text { Katılım Biçimi }\end{array}$} & $\begin{array}{l}\text { Anlaşılmayan konuları } \\
\text { anlatma }\end{array}$ & 4 \\
\hline & & Ödevlerine yardımcı olma & 3 \\
\hline & & $\begin{array}{l}\text { Uygun çalışma ortamı } \\
\text { hazırlama }\end{array}$ & 3 \\
\hline & & Konu tekrarı yaptırma & 2 \\
\hline & & Rehberlik yapma & 1 \\
\hline & & $\begin{array}{l}\text { Sinıfça yapılan etkinliklere } \\
\text { katılma }\end{array}$ & 3 \\
\hline & & Veli toplantılarına katılma & 7 \\
\hline & & $\begin{array}{l}\text { Diğer velilerle derslerle } \\
\text { ilgili görüşme }\end{array}$ & 3 \\
\hline
\end{tabular}

- Bana göre okul çocuklarım için önemlidir çünkü çocuklarımın gelecek yaşantısının belirlenmesi aldıkları eğitimle şekillenecektir. (K1)

- Ben çocuklarımın ileriki yaşantısında sahip olacağı değerleri okulda kazanacaklarına inanıyorum. Gelecek yaşantılarında, mesleklerinde, ahlaki durumlarında okulun payının çok büyük olduğuna inanıyorum. (K3) 
- Çocuk hayatta ihtiyacı olan şeyleri, matematiksel işlemler, çeoresindekilerle ilişkiler kurma gibi becerileri okulda öğrenir ve hayatı boyunca kullanır. (E3)

Suriyeli ebeveynler için aile katılımı çalışmaları, çocuklarının okuldaki başarılarını arttırmak, olumlu davranış kazandırmak, çocuğun hayata hazırlanmasını sağlamak ve okulda başlayan sürecin evde de devam etmesi için yapılan çalışmaları çağrıştırmaktadır. Bu konu ile ilgili katılımcıların görüşleri aşağıda verilmiştir.

- Aile katılımı, öğrencinin okuldaki derslerinin ve çocuğumun sergilediğ davranışların takibi ve evdeki ödevlerine yardımo olmaktır. (E1)

- Bana göre aile, çocuğun okuldaki başarısında, çeoresindeki canlılarla ilişkilerinde ve gösterdiği davranışlarda öğretmen kadar etkilidir. Eğitimde aile katılımı da çocuğu derslerindeki başarısının, çeoresindekilerle ilişkilerinin ve gösterdiği davranışların daha iyi olması için ailelerin yaptıkları her şeydir. (K6).

- Çocuk okul öncesi eğitimini ailede alır. Okula başladığında da eğitim süreci hem okul hem aile işbirliği ile gerçekleşir. Eğitimde aile katılımın okulda yapilanların evde de devam ettirilmesi ve desteklenmesi şeklinde tanımlayabilirim. (K7).

Araştırmaya katılan Suriyeli ebeveynlerin hepsi çocuklarının eğitimiyle ilgilendiklerini belirtmişlerdir. Suriyeli ebeveynler anlaşılmayan konuları anlatarak, ödevlerine yardımcı olarak, onlara uygun bir çalışma ortamı hazırlayarak, sınıfça yapılan etkinliklere ve veli toplantılarına katılarak ve rehberlik yaparak çocuklarının eğitimine katıldıkları yönünde görüş bildirmişlerdir. Katılımcıların bu konu ile ilgili görüşleri aşağıda verilmiştir.

- Çocuklarımı zaman yönetimi konusunda uyarıorum. Okul ile ilgili sorumluluklarn yerine getirmelerine yardımcı oluyorum. Anlamadikları konular bildiğim kadarıla anlatmaya çalışıyorum. Anlamadığım konu olursa öğretmenlerine sormaları konusunda onları yönlendiriyorum. Fakat kesinlikle ödevlerini ben yapmiyorum, onlara rehberlik yapıyorum diyebilirim. (K1)

- Evde, çocuğumun çalışmasına uygun bir ortam hazırladım. Ders çalışacağı zaman sessiz bir ortam sağlıyorum ona. Okulda ise simfta yapılan etkinliklere katılıyorum. Çосй̆umu okulda yalnız bırakmıyorum. Sinıf annesi ve diğer anneler beni ziyarete geliyorlar. Orada çocuklarımız için neler yapabi- 
leceğimizi konuşmaya çalışıyoruz ve sımıfta onları uygulamaya çalışıyoruz. (K4)

- Ben okulda çocuğumun sosyal ilişkilerini ve ders başarısın takip ediyorum. Öğretmeni ile çocuğumun durumunu ve evde yapmam gerekenleri konuşuyorum. Evde ise onun derslerine yardimci oluyorum. Ayrica akıl oyunlarn oynayarak onun sadece ders başarısını arttırmasını değil, zekâsını kullanmasını da öğretmeye çalışıyorum. (E3)

- Ben yabancı bir ülkeden geldim. Çocuklarım için Türkçe öğrendim. Onlara da Türkçe öğrettim. Çocuğum şu an 1. simfta öğrenim görüyor. Öğretmeni ve arkadaşlarıla iletişim kurabiliyor. Okuma ve yazma biliyor. Derslerinde başarı gösteriyor. Öğretmeni durumunun çok iyi olduğunu söylüyor. Ayrtca onu okul dışında, çocuklar için yapılan etkinliklere götürüyorum. Bu tür etkinliklerden de çocuğum yeni şeyler öğreniyor. Tüm bunlardan yola çıkarak çocuğumun eğitim sürecine katılımımı yeterli olarak görüyorum (K5)

Araştırmaya katılan Suriyeli ebeveynlerin aile katılım çalışmalarına ilişkin farkındalıklarından yola çıkarak, genel anlamda çocuklarının eğitimi konusunda hassas davrandıkları, eğitimin çocukları için önemli olduğunu düşündükleri ve bu konu ile ilgili farkındalığa sahip oldukları söylenebilir. Buna karşın Suriyeli ebeveynlerin aile katılım biçimleri incelendiğinde, ebeveynlerin bir kısmının eğitimde aile katılım çalışmalarını sadece çocuklarının ödevlerine yardımcı olma ve konu tekrarı yaptırma gibi dar bir çerçevede değerlendirdikleri anlaşılmaktadır.

\section{Suriyeli Ebeveynlere Göre Aile Katılımı Çalışmalarının Faydaları}

Araştırmada "Suriyeli Ebeveynlere Göre Aile Katılımı Çalışmalarının Faydaları" teması çerçevesinde elde edilen kodlar, alt kodlar ve alt kodların tekrarlanma sıklığı Tablo 3'de verilmiştir.

Tablo 3 incelendiğinde bu tema altında "ailenin eğitim sürecine katılımının veliye sağladığı faydalar" ve "ailenin eğitim sürecine katılımının öğrenciye sağladığı faydalar" kodlarının elde edildiği görülmektedir. Suriyeli ebeveynler, eğitim sürecine ailelerin aktif olarak katılımının kendilerine, sosyalleşme, Türkçe öğrenme, Türk kültürünü öğrenme, eğitim sistemlerini karşılaştırma, psikolojik rahatlama ve aidiyet duygusu geliştirme gibi faydalarının olduğu yönünde görüş bildirmişlerdir. 
Araştırmaya katılan Suriyeli ebeveynlerin bu konudaki görüşleri ile ilgili örnekler aşağıda verilmiştir.

Tablo 3. Suriyeli Ebeveynlerin Aile Katılımı Çalışmalarının Faydaları Hakkındaki Görüşleri

\begin{tabular}{|c|c|c|c|}
\hline Tema & Kodlar & Alt Kodlar & $\begin{array}{l}\text { Alt Kodların } \\
\text { Tekrarlanma } \\
\text { Siklığı }\end{array}$ \\
\hline \multirow{15}{*}{$\begin{array}{l}\text { Aile Katılımı } \\
\text { Çalışmalarının } \\
\text { Faydaları }\end{array}$} & \multirow{6}{*}{$\begin{array}{l}\text { Ailenin Eğitim Sü- } \\
\text { recine Katılımının } \\
\text { Veliye Sağladı̆̆ } 1 \\
\text { Faydalar }\end{array}$} & Sosyalleşme & 4 \\
\hline & & Türkçe Öğrenme & 6 \\
\hline & & Türk kültürünü öğrenme & 5 \\
\hline & & $\begin{array}{l}\text { Eğitim sistemlerini } \\
\text { karşılaştırma }\end{array}$ & 1 \\
\hline & & Psikolojik rahatlama & 2 \\
\hline & & Aidiyet duygusu geliştirme & 2 \\
\hline & \multirow{9}{*}{$\begin{array}{l}\text { Ailenin Eğitim Sü- } \\
\text { recine Katılımının } \\
\text { Öğrenciye Sağladığı } \\
\text { Faydalar }\end{array}$} & Daha başarılı olma isteği & 5 \\
\hline & & Doğru davranış geliştirme & 3 \\
\hline & & $\begin{array}{l}\text { Çocuğun iyi bir iş sahibi } \\
\text { olması }\end{array}$ & 1 \\
\hline & & Özgüven kazanma & 2 \\
\hline & & Aydın birey olma isteği & 1 \\
\hline & & Kendini güvende hissetme & 3 \\
\hline & & Aidiyet duygusu geliştirme & 1 \\
\hline & & Sorumluluk sahibi olma & 2 \\
\hline & & İletişim becerisini geliştirme & 1 \\
\hline
\end{tabular}

- Bizim şu anda normal bir hayat yaşadığımızı söyleyemem. En azından okula gelip öğretmenlerle ve Türk ailelerle karşılaşmam ve onlarla iletişim kurmaya çalışmam bile beni ruhsal olarak rahatlatıyor. Okulda yapılan çalışmalarda rol almam az da olsa Türkçe öğrenmeme katkı sağlıyor. (K2)

- Çoğu Suriyeli için Türkçe bilmeme büyük bir problem teşkil ediyor. Ben az da olsa Türkçe biliyorum. Türkçeyi anlayabiliyorum ve az da olsa konuşabiliyorum. Ben Türkçeyi okul sayesinde öğrendim. Çocuklarıma yardımcl olurken onlar bana tercüme yapıyorlar. Bu da benim Türkçe öğrenmemi sağladı. Ayrıca ben okula gelip giderken hayata bakış açım değişiyor. Bu ülkeye alışıyorum ve kendimi buraya ait hissedebiliyorum. (K3)

- Ben çocuğumun eğitimiyle ilgilendikçe Türk kültürünü daha iyi anlayabiliyorum. Çünkü okula gelip giderken ya da sinıf toplantılarında Türk ailelerle karşılaşıyorum. Onlarla az da olsa iletişim kurmaya çalışıyorum. Bu da benim sosyalleşmemi ve Türkleri tanımamı sağlıyor. (E2) 
Araştırmaya katılan Suriyeli ebeveynler, ailelerin eğitim sürecine aktif olarak katılımının çocuklarına, daha başarılı olma isteği, doğru davranış geliştirme, çocuğun iyi bir iş sahibi olması, özgüven kazanma, aydın birey olma isteği, kendini güvende hissetme, sorumluluk sahibi olma ve iletişim becerisini geliştirme gibi yönlerden fayda sağladığın belirtmişlerdir. Suriyeli ebeveynlerin bu konudaki görüşleri ile ilgili örnekler aşağıda verilmiştir.

- Benim aile katılım çalışmalarında aktif olarak rol almam, çocuklarımın kendileri için koydukları hedefe ulaşmalarına katkı sağlar. Çocuklarımın dersleri ile ilgili anlamadiklar yerlerde onlara yardımo olduğumda, çocuklarımın daha kolay öğrendiğini görüyorum. Onlar benim çabamı gördükçe daha başarılı olmaya çaba gösteriyorlar. Onların hem okuldaki başarısı artıyor hem de doğru davranışlar gösteriyorlar. (E1)

- Çocuğumun geleceğinin alacağı eğitime bağh olduğunu biliyorum. Ben ne kadar onun eğitimiyle ilgili olursam, çocuğum da o kadar başarll olur. Sinıfinda kendini küçük görmez. Annem evde ve okulda benim eğitimimle ilgileniyor der ve başarısını arttırmak için daha çok çalışır. (K2)

- Aile çocukların eğitimine aktif bir şekilde katılırsa çocuk ışıklı (aydın) bir adam olur. Nereye giderse gitsin ışığını yanında götürür ve gittiği yeri aydınlatır. Yani aile ne kadar ilgiliyse çocuk da o kadar insanlı̆̆a faydah bir birey olur. (K7)

Görüşlerden de anlaşılacağı gibi Suriyeli ebeveynlerin aile katılımı çalışmalarının faydalarını genel olarak; kendilerinin ve çocuklarının birçok kazanım elde etmesi, eğitimde aktif olduklarında kendilerini daha mutlu hissetmeleri ve bu çalışmalara kendilerini zorunlu hissetmeden aktif bir şekilde katılmaları şeklinde ifade ettikleri anlaşılmaktadır.

\section{Suriyeli Ebeveynlerin Aile Katılımı Çalışmalarında Karşılaştıkları Sorunlar}

Araştırmada "Suriyeli Ebeveynlerin Aile Katılımı Çalışmalarında Karşılaştıkları Sorunlar" teması çerçevesinde elde edilen kodlar, alt kodlar ve alt kodların tekrarlanma sıklığı Tablo 4 'te verilmiştir.

Tablo 4 incelendiğinde bu tema altında "aile katılımını engelleyen faktörler", "aile katılım çalışmalarına eşlerden herhangi birinin katılamama sebebi", "aile katılım çalışmalarına sadece bir ebeveynin katılma- 
sının açacağı sorunlar" ve "öğretmen tutumunun aile katılımına etkisi" kodlarının elde edildiği görülmektedir.

Tablo 4. Suriyeli Ebeveynlerin Aile Katılımı Çalışmalarında Karşılaştıkları Sorunlar Hakkındaki Görüşleri

\begin{tabular}{|c|c|c|c|}
\hline Tema & Kodlar & Alt Kodlar & $\begin{array}{l}\text { Alt Kodların } \\
\text { Tekrarlanma } \\
\text { Sıklığı } \\
\end{array}$ \\
\hline \multirow{21}{*}{$\begin{array}{l}\text { Suriyeli Ebev- } \\
\text { eynlerin Aile } \\
\text { Katılımı Çalışma- } \\
\text { larında } \\
\text { Karşılaştıkları } \\
\text { Sorunlar }\end{array}$} & \multirow{10}{*}{$\begin{array}{l}\text { Aile Katılımını } \\
\text { Engelleyen Faktör- } \\
\text { ler }\end{array}$} & Kültürel farklılıklar & 4 \\
\hline & & Türkçe bilmeme & 7 \\
\hline & & Eğitim sisteminin farklı olması & 2 \\
\hline & & Ağır şartlar altında çalışma & 2 \\
\hline & & Maddi yetersizlikler & 3 \\
\hline & & Sağlık problemleri & 1 \\
\hline & & $\begin{array}{l}\text { Öğrencinin okulda problem } \\
\text { çıkarması }\end{array}$ & 1 \\
\hline & & $\begin{array}{l}\text { Türk ailelerin Suriyeli aileleri } \\
\text { kabullenmemesi }\end{array}$ & 2 \\
\hline & & $\begin{array}{l}\text { Öğretmenlerin olumsuz tu- } \\
\text { tumları }\end{array}$ & 2 \\
\hline & & $\begin{array}{l}\text { Ailenin eğitim düzeyinin } \\
\text { düşük olması }\end{array}$ & 1 \\
\hline & \multirow{3}{*}{$\begin{array}{l}\text { Aile Katılımı } \\
\text { Çalı̧̧malarına } \\
\text { Eşlerden Herhangi } \\
\text { Birinin Katılamama } \\
\text { Sebebi }\end{array}$} & Eşin ağır şartlarda çalışması & 5 \\
\hline & & $\begin{array}{l}\text { Eğitime ayıracak zaman bula- } \\
\text { mama }\end{array}$ & 4 \\
\hline & & $\begin{array}{l}\text { Eşin herhangi bir eğitim al- } \\
\text { mamış olması }\end{array}$ & 2 \\
\hline & \multirow{3}{*}{$\begin{array}{l}\text { Aile Katılımı } \\
\text { Çalışmalarına } \\
\text { Sadece Bir Ebev- } \\
\text { eynin Katılmasının } \\
\text { Açacağ }{ }_{1} \text { Sorunlar }\end{array}$} & $\begin{array}{l}\text { Aktif olan kişinin çok } \\
\text { yorulması }\end{array}$ & 2 \\
\hline & & $\begin{array}{l}\text { Öğrencinin istenmeyen dav- } \\
\text { ranış göstermesine yol açma }\end{array}$ & 5 \\
\hline & & $\begin{array}{l}\text { Öğrencinin başarısız olmasına } \\
\text { neden olma }\end{array}$ & 4 \\
\hline & \multirow{5}{*}{$\begin{array}{l}\text { Öğretmenin Tutu- } \\
\text { mu }\end{array}$} & $\begin{array}{l}\text { Eğitimde aktif olma hissi } \\
\text { uyandırır }\end{array}$ & 7 \\
\hline & & $\begin{array}{l}\text { Okula karşı olumlu tutum } \\
\text { geliştirmeyi sağlar }\end{array}$ & 2 \\
\hline & & $\begin{array}{l}\text { Öğretmen ve Türk ailelerle } \\
\text { iletişimi güçlendirir }\end{array}$ & 3 \\
\hline & & $\begin{array}{l}\text { Okula karşı aidiyet duygusunu } \\
\text { geliştirir }\end{array}$ & 2 \\
\hline & & $\begin{array}{l}\text { Daha fazla çalışma ve boşluğu } \\
\text { doldurma hissi uyandırır }\end{array}$ & 5 \\
\hline
\end{tabular}


Suriyeli ebeveynler, kültürel farklılıkların, Türkçe bilmemenin, eğitim sisteminin farklı olmasının, ağır şartlar altında çalışmanın, maddi yetersizliklerin, sağlık problemlerinin, öğrencinin okulda problem çıkarmasının, Türk ailelerin Suriyeli aileleri kabullenmemesinin, öğretmenlerin olumsuz tutumlarının ve ailenin eğitim düzeyinin düşük olmasının eğitimde aile katılım çalışmalarının önündeki engeller olarak belirtmişlerdir. Araştırmaya katılan Suriyeli ebeveynlerin bu konudaki görüşleri ile ilgili örnekler aşağıda verilmiştir.

- Çocuğun okulda problem çıkarması benim için eğitimde aile katılımını engelleyen bir faktördür. Türkiye'ye ilk geldiğimizde 6. simıfa giden bir çocuğum vardl. Okulda çok büyük problemler yaşadı. O zamanlarda okula gitmek istemedim. Çocuğumun eğitimiyle ilgilenemedim. Okul toplumunun Suriyelileri kabullenmemesi de aile katılımını engelleyen bir faktördür. Türkçe bilmeme, maddi yetersizlikler ve kültürel farklılıklar da eğitimde aile katılımın engelleyen faktörlerdendir diye düşünüyorum. (E2)

- Bana göre eğitimde aile katılımını engelleyen faktörleri öğretmenlerin olumsuz tavurları, ailelerin olumsuz tavırlar, ailelerin bilgi veya eğitim düzeyinin yetersiz olması, çalışma koşulları ve zaman bulamama, kültür farklılılarna uyum sağlayamama, maddi sebepler, eğitimi gereksiz görme ve dil probleminden dolayı iletişim kuramama şeklinde sıralayabilirim (E3)

- Benim eğitimde aile katılımımı etkileyen faktörlere, Türkçe bilmememi, Suriye'deki eğitim sistemi ile Türk eğitim sisteminin birbirinden farklı olmastnı, eşimin ağır şartlar atında çalışmasından ötürü çocuklarla sadece benim ilgilenmemi gösterebilirim. (K6)

Araştırmaya katılan Suriyeli ebeveynler, aile katılım çalışmalarına ilişkin sorunlara eşlerden herhangi birinin katılamaması, eşinin ağır şartlarda çalışması, eğitime ayıracak zaman bulunamaması ve eşinin herhangi bir eğitim almamış olması gibi durumların sebep olduğunu belirtmişlerdir. Suriyeli ebeveynlerin bu konudaki görüşleri ile ilgili örnekler aşağıda verilmiştir.

- Eşim sabah çok erken gidip akşam geç saatte kadar çalışıyor. Çocuklarm eğitimine ayıracak zamanı kalmıyor. (K2)

- Çünkü eşim çalışmak zorunda. Akşam çok geç geliyor. Bu da çocuklara zaman ayıramıyor. Bir de eşim hayatı boyunca herhangi bir okulda eğitim almamış. Bu da çocukların eğitimi ile ilgilenmesine engel oluyor. (K3) 
- Ben elimden gelen her şeyi yapmaya çalışıyorum ama bir işte çalıştığım için zaman buldukça çocuklarmla ilgilenebiliyorum. Eşim ise sürekli çocuklarla birlikte olduğundan onlarm her türlü ihtiyactn karşılayabilecek zamana sahip. Bu nedenle onun çocuğumun eğitiminde daha istekli olduğunu söyleyebilirim. (E3)

Suriyeli ebeveynlere göre eşlerden sadece birinin çocuklarının eğitiminde aktif olması sorun olarak görülmektedir. Araştırmaya katılan Suriyeli ebeveynlere göre aile katılım çalışmalarına sadece bir ebeveynin katılması, eğitimde aktif olarak rol alan kişinin çok yorulmasına, öğrencinin istenmeyen davranışlar sergilemesine ve öğrencinin başarısız olması gibi sonuçlar doğurabilmektedir. Suriyeli ebeveynlerin bu konudaki görüşleri ile ilgili örnekler aşağıda verilmiştir.

- Türkiye'ye ilk geldiğimizde eşim başka bir ülkede çalışıyordu. O dönemde çocuklarm eğitimiyle sadece ben ilgilenmek zorunda kaldım. Bu durum çocuklar açısından bir sorun oluşturmadı fakat benim için bir sorundu. Çok fazla yoruluyordum. (K1)

- Çocuğun sadece dersleri ile ilgili eğitiminde değil, davranış eğitiminde de anne ve baba birlikte aktif olarak rol almalıdır. Çünkü biri eksik olursa, çocuk da eksik olarak yetişir. Bu nedenle hem anne hem de baba birlikte çocuğun eğitiminde aktif olmalıdır. (E2)

- Ben ders başarısı olarak bir sorun oluşturduğunu düşünmüyorum ama davranışsal olarak büyük sorunlara yol açacağını düşünüyorum. Çünkü çocuklar hem anneden hem babadan bir şeyler öğreniyorlar. Sadece anne ya da sadece baba çocuklarm eğitimiyle ilgilenirse çocuklarm bir tarafı hep eksik kalacaktır. (K5)

Araştırmaya katılan Suriyeli ebeveynler, çocuklarının öğretmeninin kendilerine karşı sergilediği tutumların, olumlu olması halinde aile katılım çalışmalarına karşı heveslerini arttırdığı yönünde görüş bildirmişlerdir. Suriyeli ebeveynlere göre öğretmenin olumlu tutumları, kendilerinde eğitimde aktif olma güdüsü, okula karşı olumlu tutum geliştirme, öğretmen ve Türk ailelerle iletişim kurma isteği, okula karşı aidiyet duygusu geliştirme, daha fazla çalışma ve boşluğu doldurma hissi uyandırma gibi etkiler sağlayacaktır. Araştırmaya katılan Suriyeli ebeveynlerin bu konudaki görüşleri ile ilgili örnekler aşağıda verilmiştir.

- Öğretmenin tutumu benim eğitime katılımımı elbette etkiler. Bana göre bir çocuğun eğitiminde lider yani önde giden kişi öğretmendir. Öğretmen bana 
karşı olumlu tutum sergilediğinde, ben çocuklarımın eğitimine daha aktif olmam gerektiğini hissediyorum. (E1)

- Öğretmenin tutumu benim aile katılımım noktasında çok büyük öneme sahiptir. Öğretmen öğrenciyi yönlendirdiği gibi aslında velileri de yönlendirmektedir. Öğretmen bizi iyi yönlendirir ve çocuklarımızın eğitim sürecinde aktif olmamızı isterse, biz okula, öğretmene ve Türk ailelere karşı sıcak duygular besleyebiliriz. (K6)

- Çосй̆umun öğretmeninin tutumu benim eğitimde aktif olarak katılımımı önemli ölçüde etkiler. Öğretmen olumlu tutum sergilerse bizler de çocuğumuzun eğitimiyle daha fazla ilgilenir ve çocuğumuzun eğitimi için gerekli olan her şeyi eksiksiz olarak yapmaya çalışırız. (K7)

Genel olarak Suriyeli ebeveynlerin görüşlerinden, aile katılım çalışmalarında karşılaştıkları sorunlardan ötürü sıkıntı yaşadıkları, bu sorunların genel olarak yaşam standartlarının düşük olmasından kaynaklandığı ve bu durumun hayatlarının tümünde olduğu gibi çocuklarının eğitim sürecinde de birtakım sıkıntılara yol açtığı fakat kendi imkânları dâhilinde bu sıkıntıları aşmak için çabaladıkları anlaşılmaktadır. Eğitim sürecinde öğretmenlerin olumlu tutumlarının, Suriyeli ebeveynleri okula karşı daha yakın duygular geliştirmelerini sağlayacağı ve eğitim sürecinde onları daha aktif kılabileceği söylenebilir.

\section{Suriyeli Ebeveynlerin Aile Katılımı Çalışmaları Hakkındaki Beklenti- leri}

Araştırmada "Suriyeli Ebeveynlerin Aile Katılımı Çalışmaları Hakkındaki Beklentileri" teması çerçevesinde elde edilen kodlar, alt kodlar ve alt kodların tekrarlanma sıklığı Tablo 5'te verilmiştir.

Tablo 5 incelendiğinde bu tema altında "Türk ailelerden beklentiler", "sinıf öğretmeninden beklentiler" ve "okul yönetiminden beklentiler" kodlarının elde edildiği görülmektedir. 
Tablo 5. Suriyeli Ebeveynlerin Aile Katılımı Çalışmaları Hakkındaki Beklentileri

\begin{tabular}{|c|c|c|c|}
\hline Tema & Kodlar & Alt Kodlar & $\begin{array}{l}\text { Alt Kodların } \\
\text { Tekrarlanma } \\
\text { Sıklığı }\end{array}$ \\
\hline \multirow{17}{*}{$\begin{array}{l}\text { Suriyeli Ebev- } \\
\text { eynlerin Aile } \\
\text { Katılımı } \\
\text { Çalışmaları } \\
\text { Hakkındaki } \\
\text { Beklentileri }\end{array}$} & \multirow{5}{*}{$\begin{array}{l}\text { Türk Ailelerden } \\
\text { Beklentiler }\end{array}$} & $\begin{array}{l}\text { Suriyelileri kabullenmeleri } \\
\text { beklentisi }\end{array}$ & 4 \\
\hline & & $\begin{array}{l}\text { Maddi yardım için okula } \\
\text { gelmediklerinin farkına varıl- } \\
\text { ması }\end{array}$ & 1 \\
\hline & & $\begin{array}{l}\text { Yapilan etkinliklere davet } \\
\text { edilme }\end{array}$ & 4 \\
\hline & & Okula birlikte gidip gelme & 1 \\
\hline & & $\begin{array}{l}\text { Sosyal ortamlarda birlikte } \\
\text { hareket etme }\end{array}$ & 3 \\
\hline & \multirow{6}{*}{$\begin{array}{l}\text { Sinıf Öğretmeninden } \\
\text { Beklentiler }\end{array}$} & $\begin{array}{l}\text { Öğrenci hakkında ayrıntılı } \\
\text { bilgi verme }\end{array}$ & 1 \\
\hline & & $\begin{array}{l}\text { Türk ve Suriyeli velileri eşit } \\
\text { görme }\end{array}$ & 5 \\
\hline & & $\begin{array}{l}\text { Öğrencinin geleceğinin } \\
\text { ellerinde olduğunun farkına } \\
\text { varma }\end{array}$ & 3 \\
\hline & & $\begin{array}{l}\text { Suriyeli veli ve öğrencilere } \\
\text { daha fazla ilgi gösterme }\end{array}$ & 3 \\
\hline & & $\begin{array}{l}\text { Öğretmenlerin Arapça } \\
\text { öğrenmesi }\end{array}$ & 1 \\
\hline & & $\begin{array}{l}\text { Eğitimde aktif velileri takdir } \\
\text { etme }\end{array}$ & 1 \\
\hline & \multirow{6}{*}{$\begin{array}{l}\text { Okul Yönetiminden } \\
\text { Beklentiler }\end{array}$} & $\begin{array}{l}\text { Suriyelileri kendilerinden biri } \\
\text { olarak görme }\end{array}$ & 3 \\
\hline & & $\begin{array}{l}\text { Türkçe dil ve okuma yazma } \\
\text { kursu açma }\end{array}$ & 5 \\
\hline & & $\begin{array}{l}\text { Türk ve Suriyelileri } \\
\text { kaynaştıracak etkinlikler } \\
\text { düzenleme }\end{array}$ & 4 \\
\hline & & $\begin{array}{l}\text { Oryantasyon etkinlikleri } \\
\text { düzenleme }\end{array}$ & 1 \\
\hline & & $\begin{array}{l}\text { Eğitimde aktif olan velilerin } \\
\text { ödüllendirilmesi }\end{array}$ & 1 \\
\hline & & $\begin{array}{l}\text { Milli bayramlarda Suriyeli veli } \\
\text { ve öğrencilere görev verme }\end{array}$ & 1 \\
\hline
\end{tabular}

Araştırmaya katılan Suriyeli ebeveynlerin hepsi, Türk ailelerden birtakım beklentileri olduğunu dile getirmişlerdir. Suriyeli ebeveynler Türk ailelerden, kendilerini kabullenmelerini, sadece maddi yardım alabilmek 
maksadıyla okula gelmediklerinin farkına varmalarını, yapılan etkinliklere Suriyeli aileleri de davet etmelerini, okula geliş ve gidişlerde kendilerinin de Türk ebeveynler tarafından çağrılmasını ve sosyal ortamlarda kendileriyle birlikte hareket etmelerini beklediklerini söylemişlerdir. $\mathrm{Bu}$ konu ile ilgili Suriyeli ebeveynlerin görüşleri ile ilgili örnekler aşağıda verilmiştir.

- Bazı aileler bizlerle Suriyeli diye dalga geçiyorlar. Bazı Türk aileler bizim okula gelme sebebimizin maddi yardım almak olduğunu söylüyorlar. Ama kendi adıma bunun doğru olmadığın söyleyebilirim. Bugüne kadar maddi hiçbir yardım almadım. Ben kendimi bu ülkenin vatandaşı olarak görüyorum. Türk ailelerden, bizim de insan olduğumuzu unutmamaların ve bizi kabullenmelerini bekliyorum. Okulda yapılacak etkinliklere beni de davet etmelerini bekliyorum. (K1)

- Benim Türk ailelerden eğitim sürecinden ziyade sosyal yaşam açısından birtakım beklentilerim var. Onlarm insani pencereden bakmalarım bekliyorum. Bizi gördüklerinde Suriyeli diye hor gördüklerini hissediyorum. Kendi çocuklarımı bizim çocuklarımızla oturmasından bile rahatsız olanlar var. Bu durumda biz çocuklarımızın eğitim sürecine katılmaktan çekiniyoruz. Okulda yapılanlar etkinliklere katılmak istemiyoruz. Ben Türk ailelerden bizi kendilerinden biri olarak görmelerini ve bizi eğitim sürecine katılımımız noktasında istekli hale getirecek davranışlarda bulunmalarmı bekliyorum. (K4)

- Bizim özel durumumuzun farkında olmalarm bekliyorum. Bizim de Suriye'de okulumuz, evimiz ve işimiz vardı. Kim güzel olan bir hayatı bırakıp başka bir yere gider? Biz ülkemizdeki savaştan kaçıp Türkiye'ye sığındık. Türk aileler kapımızı çalsalar, çocukların ödevi bu deseler, yapılacak şeyleri söyleseler, Suriyeli aileler eğitimde daha aktif olurlar diye düşünüyorum. (E3)

Suriyeli ebeveynlerin hepsi sınıf öğretmeninden de birtakım beklentileri olduğunu belirtmişlerdir. Suriyeli ebeveynler sınıf öğretmenlerinden Türk ve Suriyeli velileri eşit görme, çocuklarının geleceğinin ellerinde olduğunun farkına varma, Suriyeli veli ve öğrencilere daha fazla ilgi gösterme, öğretmenlerin Arapça öğrenmesi, eğitimde aktif velileri takdir etme gibi beklenti içinde oldukları yönünde görüş bildirmişlerdir. Bu konu ile örnek verilebilecek görüşler aşağıda verilmiştir. 
- Benim çocuklarım okulda çok başarllı. Bu durum öğretmenlerin sayesinde gerçekleşiyor. Başka şehirlerde yaşayan akrabalarımla konuştuğumuzda öğretmenlerin tutumlarından şikâyet ediyorlar. Ben ailelerin çocuklarının eğ $i$ timiyle ilgilenmesinde öğretmenlerin tutumlarının çok etkili olduğuna inanıyorum. Öğretmenlerden beklentilerim anne babalara çocukları hakkında bilgiler versin. Suriyeli aileleri de kendi velileri olarak görsünler. Öğrencilerin geleceklerinin kendi ellerinde olduğunun farkında olsunlar. (E1)

- Yaşadiklarımızı göz önünde bulundurarak Suriyeli öğrencilerin ve ailelerinin Türk öğrenci ve ailelerinden daha şanssız olduklarm söyleyebilirim. Öğretmenlerden beklentilerim bu gerçeği göz ardı etmemeleri ve Türk öğrencilerin hakkını yemeyecek şekilde, Suriyeli öğrencilerle daha fazla ilgilenmelerini bekliyorum. (K5)

- Ben bu ülkede yaşıyorsam Türkçe öğrenmek zorundayım. Ama öğretmenlerimiz de hem bize hem çocuklarımıza hem de kendilerine fayda sağlaması açısından Arapça öğrenmelerini bekliyorum. Bu şekilde hem dil öğrenmiş olurlar hem de bizi eğitimde daha aktif olmamızı sağlarlar. (K7)

Suriyeli ebeveynler okul yönetiminden, Suriyelileri kendilerinden biri olarak görmelerini, Türkçe dil ve okuma yazma kursu açmalarını, Türk aileleri ve Suriyeli aileleri kaynaştıracak etkinlikler düzenlemelerini, oryantasyon etkinlikleri düzenlemelerini, eğitimde aktif olan Suriyeli velilerin ödüllendirilmesini ve milli bayramlarda Suriyeli veli ve öğrencilere görev vermelerini beklemektedirler. Araştırmaya katılan Suriyeli ebeveynlerin bu konudaki görüşleri ile ilgili örnekler aşağıda verilmiştir.

- Bizim en büyük problemlerimizden biri Türkçe bilmeme. Okul idaresinden, Suriyeli ailelerin dil problemini çözmek için Türkçe kursu açmasım bekliyorum. Dil kursu ile birlikte Türkçe okuma yazma kursu açmalarm bekliyorum. Dil problemi ve okuma yazma problemi olmayan anne babalarm, çocuklarının eğitimine daha fazla katılacağın düşünüyorum. Ayrıca Türk anneler ile kaynaşacağımı etkinliklerin yapılabileceğini düşünüyorum. (K2)

- Bizim çocuklarımızın eğitim sürecine katılımımız için öncelikle okulu, öğretmenleri, eğitim sistemini ve Türk kültürünü tanımamız gereklidir. Çünkü buradaki sistem Türkler için oluşturulmuştur. Öğrenci ve velilere okula başlayacakları zaman, uyum etkinlikleri yapılarak okulu ve öğretmenleri, eğitim sisteminin ve Türk kültürünü tanıtıcı etkinlikler yapmalarım bekliyorum. (E2) 
- Okul idaresi Türkçe kursu açabilir. Dil problemini çözen aileler çocuklartnın eğitim sürecinde daha aktif olurlar. Cumhuriyet Bayramı, Çocuk Bayramı gibi özel günlerde Suriyeli ailelere de görev versinler. Okulun güzel yüzünü ailelere göstersinler. Türk ailelerle Suriyeli aileleri kaynaştıracak etkinlikler yapsinlar. Bu şekilde insanlar birbirine daha sicak duygular beslerler. Bunun sonucunda da Suriyeli aileler çocuklarının eğitiminde daha aktif olurlar. (E3)

Genel olarak Suriyeli ebeveynlerin kendilerini öğretmenler ve Türk ebeveynler tarafından dışlanmış olarak gördükleri, öğretmen, Türk ebeveynler ve okul yöneticilerinden bu konuda eşit bir tutum sergilemelerini bekledikleri anlaşılmaktadır. Suriyeli ebeveynler, Türkçe öğrenerek ve Türk ebeveynlerle daha yakın ilişkiler kurarak bu sorunu ortadan kaldırabileceklerini düşünmektedirler.

\section{Sonuç, Tartışma ve Öneriler}

$\mathrm{Bu}$ araştırma Suriyeli ebeveynlerin ilkokulda aile katılımına ilişkin görüşlerini belirlemek amacıyla yapılmıştır. Araştırmadan elde edilen bulgulara göre, Suriyeli ebeveynlerin tamamının, okulu çocukları için önemli gördükleri anlaşılmıştır. Okulu önemli görmelerinin nedenlerini ise eğitimin çocuklarının; gelecek yaşantılarını şekillendirmesi, insani değerleri ve temel becerileri kazandırması ile diğer bireylerle ve canlılarla olan iletişimlerini güçlendirmesi olarak belirtmişlerdir. Göçmen ebeveyn desteğinin eğitime çekilebilmesi için öğretmenlerin göçmenlerin kültürünü anlaması gerekir. Bunu yapmak, göçmenler hakkında birçok yanlış anlamayı ortadan kaldıracaktır. Ancak o zaman öğretmenler onları okulda hoş karşılandıklarına ikna etmeyi umabilirler (Tebben, 2017). Okul ve aile arasındaki bağ hem Suriyeli ailelerin hem de okulun birbirlerinin deneyimlerinden karşılıklı olarak faydalanılabilecek şekilde oluşturulmalıdır. Suriyeli ebeveynler eğitime daha fazla dâhil oldukça, okul ile aralarında kurdukları bağ güçlenecek ve çocuklarını akademik olarak nasıl destekleyeceklerini öğreneceklerdir.

Araştırmada aile katılım çalışmalarının Suriyeli ebeveynlere, çocuklarının okuldaki başarılarını arttırmak, olumlu davranış kazandırmak, çocuğun hayata hazırlanmasını sağlamak ve okulda başlayan sürecin evde de devam etmesi için yapılan çalışmaları çağrıştırdığı sonucuna 
ulaşılmıştır. Aynı şekilde Türk aileleriyle yaptıkları araştırmada Erkan, Uludağ ve Dereli'nin (2016) aile katılımı çalışmalarının ebeveynler tarafından çocuğun okuldaki eğitimini desteklemek ve çocuğa model olmak/rehberlik yapmak olarak tanımladıkları belirlenmiştir. Binicioğlu (2010) da çalışmasında Türk ebeveynlerin aile katılım çalışmalarını, çocukla bire bir ilgilenmek olarak tanımladıklarını tespit etmiştir. Yapılan çalışmaların sonuçlarına göre Türk ve Suriyeli ebeveynlerin aile katıl1mına ilişkin algılarının benzer olduğu söylenebilir.

Araştırmaya katılan Suriyeli ebeveynler, anlaşılmayan konuları anlatarak, ödevlerine yardımcı olarak, uygun bir çalışma ortamı hazırlayarak, sınıfça yapılan etkinliklere ve veli toplantılarına katılarak ve rehberlik yaparak çocuklarının eğitimine katıldıkları yönünde görüş bildirmişlerdir. Türk ailelerle yaptığı çalışmasında Atakan (2010) ebeveynlerin çocuklarının eğitim sürecine katılımını, veli toplantılarına giderek ve öğretmenlerle yüz yüze görüşmeler yaparak gerçekleştirdiklerini tespit etmiştir. Binicioğlu (2010) ve Şeker (2009) de yaptıkları çalışmalarında Türk ailelerin yüz yüze görüşmeler yaparak ve veli toplantılarına katılarak öğretmenlerle iletişim kurdukları ve eğitim süreci içinde yer aldıkları sonucuna ulaşmışlardır. Araştırma sonuçlarından her iki gruptaki ailelerin okuldaki aile katılımı etkinliklerine benzer şekilde katıldıkları anlaşılmaktadır.

Araştırma sonuçları, Suriyeli ebeveynlerin aile katılımı çalışmalarının kendilerine önemli faydalar sağladığı konusunda hemfikir olduklarını göstermiştir. Suriyeli ebeveynler, eğitim sürecine aktif olarak katılmalarının; sosyalleşmelerine, Türkçe öğrenmelerine, Türk kültürünü öğrenmelerine, eğitim sistemlerini karşılaştırmalarına, psikolojik rahatlama ve aidiyet duygusu geliştirmelerine faydasının olduğu yönünde görüş bildirmişlerdir. Tebben (2017) yaptığı çalışmasında yapılan bu araştırmada da belirtildiği gibi göçmen ebeveynlerin eğitim sürecine katılımının dil probleminin çözümüne katkı sağladığını belirtmiştir. Suriyeli ebeveynlere göre eğitim sürecine aktif olarak katılmalarının çocuklarına da faydaları vardır. Ailelerin eğitim sürecine aktif olarak katılımının çocuklarına, daha başarılı olma isteği, doğru davranış geliştirme, çocuğun iyi bir iş sahibi olması, özgüven kazanma, aydın birey olma isteği, kendini güvende hissetme, sorumluluk sahibi olma ve iletişim becerisini geliştirme yönlerden fayda sağladığını belirtmişlerdir. Lahaie'nin (2008) yaptığı 
araştırmanın sonucunda da göçmen ailelerin eğitim sürecine katılımları arttığında, çocukların akademik başarılarının da arttığı belirtilmiştir. Ayrıca araştırmacılara göre, çocukların okulla ilgili faaliyetlerine ebeveynlerin katılımının, çocukların akademik başarıları, bilişsel gelişimleri ve İngilizce yetenekleriyle doğrudan ilişkili olduğu (Jung and Zhang, 2016), ebeveynlerin gelişimi ve çocukların akademik başarılarının artması için ebeveynlerin çocuklarının eğitimine dâhil olması gerektiği belirtilmiştir (Johnson, Avrevalo, Cates, Weisleder, Dreyer and Mendelsohn, 2016; Behtoui andNeergaard, 2015; Taylor, Larsen-Rife, Conger and Widaman, 2012).

Suriyeli ebeveynler, kültürel farklılıkların, Türkçe bilmemenin, eğitim sisteminin farklı olmasının, ağır şartlar altında çalışmanın, maddi yetersizliklerin, sağlık problemlerinin, öğrencinin okulda problem çıkarmasının, Türk ailelerin Suriyeli aileleri kabullenmemesinin, öğretmenlerin olumsuz tutumlarının ve ailenin eğitim düzeyinin düşük olmasının eğitimde aile katılım çalışmalarının önündeki engeller olarak belirtmişlerdir. Bu konuda yapılmış olan çalışmalar ile bu araştırmanın sonuçları birbiriyle örtüşmektedir. Literatürde yer alan araştırmaların sonuçlarına göre, ailelerin eğitimi gereksiz görmeleri (Crities, 2008; Erdoğan ve Demirkasımoğlu, 2010), dil problemleri (Tebben, 2017, Tümkaya ve Çopur, 2020), çalışma koşulları (Crities, 2008; Orçan Kaçan, Kimzan, Güler Yıldız ve Çağdaş, 2019) ve kültürel farklılıklar (Shannon, 1996) ailelerin eğitim sürecine katılımında engel teşkil etmektedir.

Araştırmaya katılan Suriyeli ebeveynler, öğretmen tutumlarının aile katılım çalışmalarında aktif olmalarını etkilediğini belirtmişlerdir. Suriyeli ebeveynler öğretmenlerin kendilerine ve çocuklarına karşı olumlu tutum sergilendiğinde, aile katılım çalışmalarında daha aktif bir şekilde rol alabileceklerini, okula karşı olumlu tutum geliştirebileceklerini öğretmen ve Türk ailelerle iletişimlerinin güçlenebileceğini söylemişlerdir. Bu durum çocuklar için de aynı sonuçları doğurmaktadır. Yapılan araştırmalar incelendiğinde, göçmen çocukların okullarda benimsendiklerini hissetmesi, onların özgüvenlerinin artmasına dolayısıyla da okul ile aile arasındaki bağın da güçlenmesini sağladığını göstermektedir (Block, Cross, Riggs and Gibbs, 2014; Moinolnolki and Han, 2017).

Araştırmada Suriyeli ebeveynlerin aile katılım çalışmalarında daha aktif olma konusunda Türk ailelerden, sınıf öğretmenlerinden ve okul 
yöneticilerinden birtakım beklentileri olduğu görülmektedir. Hepsinin ortak görüşü, kendilerini bu ülkenin bir parçası olarak görülüp kabullenilmeleri yönündedir. Balkar (2009) yaptı̆̆ çalışmada, bu araştırmadakine benzer sonuçlar elde etmiş, okul yönetiminin ve öğretmenlerin ailelere daha yakın ve ilgili davranmasının okul ile olan iletişimlerini artıracağını belirtmiştir. Sonuçlardan Suriyeli ebeveynlerin okulda yapılan etkinliklere katılım konusunda istekli oldukları anlaşılmıştır. Suriyeli ebeveynler kendilerini Türk ebeveynlerle kaynaştıracak etkinliklerin düzenlemesini beklemektedirler. Ayrıca Suriyeli ebeveynlerin hepsi dil problemini ortadan kaldırmak için düzenlenebilecek kurslara katılım noktasında fikir birliği içinde olduklarını bildirmişlerdir.

Sonuç olarak Mersin İli Tarsus İlçesindeki ilkokullarda çocukları öğrenim görmekte olan Suriyeli ebeveynlerin görüşleri doğrultusunda elde edilen bulgular dikkate alındığında şu öneriler getirilebilir:

- Suriyeli ebeveynler ve çocuklar için, iletişim probleminin önüne geçmek adına okullarda tercüman istihdam edilebilir.

- Suriyeli ebeveynler için aile katılım çalışmalarının önündeki en temel engellerden biri Türkçe bilmemeleridir. Bu problemin çözümü için Türkçe kursları açlabilir. Bu kurslarda Türkçe öğretilmesinin yanında Türkçe okuma ve yazma dersleri de verilebilir.

- Araştırmaya katılan Suriyeli ebeveynlerin demografik özelliklerinden yola çıkarak, Suriyeli ebeveynlerin birden fazla çocukları olduğu görülmekte ve bu durum aile katılım çalışmalarının önünde bir engel olarak düşünülmektedir. Okula gelemeyen ve aile katılım çalışmaları için zaman bulamayan ebeveynler için ev temelli etkinlikler hazırlanıp ebeveynler sürece dâhil edilebilir.

- Suriyeli ebeveynlerin okulda yaşanan gelişmelerden haberdar olabilmeleri için çevrimiçi uygulamalardan faydalanılabilir. İletişim grupları oluşturularak tercüman aracılığıyla duyurular yapilabilir.

- Suriyeli ebeveynlerin okula ve sınıfa karşı aidiyet duygusu geliştirmeleri ve kendilerini okulun ve sınıfın bir parçası olarak görmelerini sağlamak adına, sınıf öğretmenleri Türk velilerle işbirliği yaparak, Suriyeli velileri ziyaret edebilir. 
- Türk ve Suriyeli ebeveynlerin birbirlerini daha iyi tanıyacakları, ortak yapılacak görevlerle birbirleriyle kaynaşacakları kermes, dinleti vb. etkinlikler düzenlenebilir.

- Milli bayram ve belirli gün ve haftalar için hazırlanacak olan programlarda, Suriyeli ebeveynlerin Türk kültürünü tanımaları ve Türkiye'ye karşı aidiyet duygusu geliştirmeleri adına Suriyeli ebeveynlere görevler verilebilir.

- Rehber öğretmenler tarafından, Suriyeli ebeveynlerin eğitim sürecine dahil edilmesine, onların görüş ve önerilerinin öğrenilmesine imkan tanıyacak görüşme ya da tarama çalışmaları yapılabilir.

- Türk ve Suriyeli ebeveynlerin birbirlerini daha iyi tanıyabilmeleri için "Kardeş Aile" uygulaması hayata geçirilebilir. Bu uygulama ile bir Türk aile ve bir Suriyeli ailenin belirli zaman aralıklarında bir araya gelip, çocuklarının eğitimi ile ilgili konuları, sosyal ve kültürel konuları, birbirlerinin örf ve adetlerini konuşabilmeleri, birbirlerinin daha iyi tanıyı empati kurabilmeleri sağlanabilir. 


\title{
EXTENDED ABSTRACT
}

\section{Investigation of Syrian Parents' Views on Parental Involvement in Primary School}

\author{
Songül Tümkaya - Ersin Çopur \\ Çukurova University
}

There are many factors that affect students' academic achievement, behavior, and communication processes with others. Family is one of the first factors that come to mind. In order to contribute to the success of their children and to ensure that they are prepared for life in a higher quality education-teaching environment, parents must first get to know their children in all aspects. It cannot be said that parents who do not know their children well enough, do not have an idea about their behavior, and are not aware of their interests and needs, are successful in preparing their children for life (Aslanargun, 2007).

It is almost impossible to reach the goals desired to be achieved at school without the support of the family. One of the ways to reach the goals more easily is to inform the families about what is done at school (Tümkaya and Çopur, 2020). The first thing to do is to determine the opinions of Syrian parents about family participation in education. This study is important because it can be a guide in determining the views of Syrian parents about family participation in primary school and planning activities that will enable Syrian parents to take a more active role in family participation studies as a result of these determinations. From this point of view, this study aimed to determine the views of Syrian parents on family participation in primary school. In line with this aim, answers to the following questions were sought:

- What is the awareness of Syrian parents regarding family participation studies?

- What are the views of Syrian parents on the benefits of their active participation in the education process for themselves and their children?

- What are the views of Syrian parents on the problems they encounter in family participation studies? 
- What are the views of Syrian parents regarding their expectations from Turkish parents, classroom teachers, and school administrations in family participation studies?

In this study, phenomenology design, one of the qualitative research methods, was used in order to obtain detailed information about the thoughts of Syrian parents about their participation in primary school.

The study group of the research consisted of 10 Syrian parents (7 Syrian mothers and 3 Syrian fathers) whose children are studying in primary schools in Mersin Province Tarsus District. The study group was formed by using the snowball sampling method, one of the purposeful sampling designs.

A semi-structured interview form was used in the research. In the interview form, there were 16 open-ended questions formed around the awareness level of Syrian families about family participation, the benefits of family participation, the problems they face in family participation, and their expectations. In the analysis of the data obtained from the research, content analysis, one of the qualitative data analysis methods, was used and the obtained findings were interpreted. In this study, as Y1ld1rım and Şimşek (2016) stated, data were coded in the first stage, themes were created in the second stage, codes and themes were arranged in the third stage, and the findings were defined and interpreted in the fourth stage. In order to increase the reliability of the research, the opinions of the participants were quoted and presented.

The findings are given under four main headings according to the themes obtained as a result of the content analysis. These titles are "Syrian Parents' Awareness of Family Participation Studies", "The Benefits of Family Participation Studies According to Syrian Parents", "The Problems Syrian Parents Encounter in Family Participation Studies" and "Syrian Parents' Expectations about Family Participation Studies".

Awareness of Syrian Parents on Family Participation Studies: It is seen that the codes of "the importance of the school", "what does family participation studies mean" and "the way of participation in the education of the student" are obtained under this theme. Syrian parents stated that they consider school important because education shapes students' future lives, the school provides students with human values and basic 
skills, and it strengthens students' communication with other individuals and living things around them.

Benefits of Family Participation Studies According to Syrian Parents: It is seen that the codes "benefits of the participation of the family in the education process to the parents" and "benefits of the participation of the family in the education process to the student" are obtained under this theme. Syrian parents stated that the active participation of families in the education process benefits them such as socializing, learning Turkish, learning Turkish culture, comparing education systems, psychological relaxation, and developing a sense of belonging. The Problems Syrian Parents Encounter in Family Participation Studies: Syrian parents stated that cultural differences, not knowing Turkish, different education system, working under harsh conditions, financial inadequacies, health problems, students causing problems at school, Turkish families not accepting Syrian families, negative attitudes of teachers and low level of education of the family are obstacles to family participation in education.

Syrian Parents' Expectations about Family Participation Studies: All of the Syrian parents who participated in the study stated that they had some expectations from Turkish families. Syrian parents expect Turkish families to accept themselves, to realize that they do not come to school only to receive financial aid, to invite Syrian families to events, to be invited by Turkish parents to come and go to school, and to act with them in social environments. Syrian parents stated that they expect classroom teachers to see Turkish and Syrian parents as equal, to realize that the future of their children is in their hands, to show more interest to Syrian parents and students, to learn Arabic, and to appreciate active parents in education. Syrian parents expect from the school management that, seeing Syrians as one of their own, opening Turkish language and literacy courses, organizing activities that will bring Turkish and Syrian families together, organizing orientation activities, rewarding Syrian parents who are active in education.

This research was conducted to determine the views of Syrian parents on family participation in primary school. According to the findings obtained from the research, it was understood that all Syrian parents consider school important for their children. The bond between school and family should be established in such a way that both Syrian families and 
the school can benefit from each other's experiences. As Syrian parents become more involved in education, their bond with the school will become stronger and they will learn how to support their children academically.

In the research, it was concluded that family participation studies remind Syrian parents of the efforts to increase their children's success at school, to gain positive behavior, to prepare the child for life, and to continue the process that started at school at home. Likewise, in their study with Turkish families, it was determined that Erkan, Uludağ, and Dereli (2016) defined family involvement activities as supporting the child's education at school and being a model/guiding the child by the parents. Binicioğlu (2010) also found in his study that Turkish parents define family involvement activities as dealing with the child one-on-one. According to the results of the studies, it can be said that the perceptions of Turkish and Syrian parents about family participation are similar.

The results of the research showed that Syrian parents agreed that family involvement studies provided significant benefits for them. Tebben (2017) stated that the participation of immigrant parents in the education process contributes to the solution of the language problem, as stated in this study conducted in their study. As a result of Lahaie's (2008) research, it was stated that when the participation of immigrant families in the education process increases, the academic success of the children also increases. Syrian parents stated that, cultural differences, not knowing Turkish, different education system, working under harsh conditions, financial inadequacies, health problems, students causing problems at school, Turkish families not accepting Syrian families, negative attitudes of teachers and low education level of the family is an obstacle to family participation studies.

In the research, it is seen that Syrian parents have some expectations from Turkish families, classroom teachers, and school administrators to be more active in family participation studies. The common view of all of them is that they should be seen and accepted as a part of this country. As a result, considering the findings obtained in line with the opinions of Syrian parents whose children are studying in primary schools in Tarsus, Mersin, the following suggestions can be made: 
- Interpreters can be employed at schools to avoid communication problems for Syrian parents and children.

- One of the main obstacles to family participation studies for Syrian parents is that they do not speak Turkish. Turkish courses can be opened to solve this problem. In these courses, besides teaching Turkish, Turkish reading and writing lessons can also be given.

- Based on the demographic characteristics of the Syrian parents participating in the research, it is seen that the Syrian parents have more than one child, and this is considered as an obstacle to family participation studies. Home-based activities can be prepared for parents who cannot come to school and cannot find time for family participation studies and parents can be included in the process.

- Online applications can be used so that Syrian parents can be informed about the developments at school. Announcements can be made through a translator by creating communication groups.

- In order for Syrian parents to develop a sense of belonging to the school and the classroom and to see themselves as a part of the school and the classroom, classroom teachers can visit Syrian parents in cooperation with Turkish parents.

- A bazaar, concert, etc., where Turkish and Syrian parents will get to know each other better and mingle with each other through joint tasks. events can be arranged.

- In the programs to be prepared for national holidays and certain days and weeks, Syrian parents can be assigned tasks so that Syrian parents get to know Turkish culture and develop a sense of belonging to Turkey.

- Counselors can conduct interviews or screening studies that will allow Syrian parents to be included in the education process and to learn their opinions and suggestions.

- "Friendly Family" application can be implemented so that Turkish and Syrian parents can get to know each other better. With this application, it can be ensured that a Turkish family and a Syrian family come together at certain intervals to talk about their children's education, social and cultural issues, each other's customs and traditions, and get to know and empathize with each other better. 


\section{Kaynakça / References}

Akkaya, A. (2013). Suriyeli mültecilerin Türkçe algıları. EKEV Akademi Dergisi, 17 (56), 179-190.

Argon, T. ve Kıyıcı, C. (2012). İlköğretim kurumlarında ailelerin eğitim sürecine katılımlarına yönelik öğretmen görüşleri. Dicle Üniversitesi Ziya Gökalp Ĕ̆itim Fakültesi Dergisi, 19, 80-95.

Aslanargun, E. (2007). Okul - aile işbirliği ve öğrenci başarısı üzerine bir tarama çalışma. Manas Üniversitesi Sosyal Bilimler Dergisi, 18, 119-135.

Atakan, H. (2010). Okulöncesi eğitiminde aile katılımı çalışmalarının öğretmen ve ebeveyn görüşlerine göre değerlendirilmesi (Yüksek Lisans Tezi, Çanakkale Onsekiz Mart Üniversitesi, Çanakkale). Erişim adresi: https://tez.yok.gov.tr/UlusalTezMerkezi/tezSorguSonucYeni.jsp

Babbie, E. (2010). The practice of social research. Belmont, CA: Wadsworth.

Balkar, B. (2009). Okul- aile işbirliği sürecine ilişkin veli ve öğretmen görüşleri üzerine nitel bir çalışma. Çukurova Üniversitesi Eğitim Fakültesi Dergisi, 3(36), 105-123.

Binicioğlu, G. (2010). İlköğretimde okul-aile iletişim etkinlikleri: Öğretmen ve veli görüşleri (Yüksek Lisans Tezi, Anadolu Üniversitesi, Eskişehir). Erişim adresi: https://tez.yok.gov.tr/UlusalTezMerkezi/tezSorguSonucYeni.jsp

Block, K., Cross,S., Riggs, E., and Gibbs, L.(2014).Supporting schools to create an inclusive environment for refugee students. International Journal of Inclusive Education,18(12),1337-1355.

Behtoui, A., and Neergaard, A. (2015). Social capital and the educational achievement of young people in Sweden. British Journal of Sociology of Education, 37, 947-969.

Creswell, J. W. (2007). Qualitative Inquiry and Research Design Choosing Among Five Approaches. Sage Publications.

Crites, C. V. (2008). Parent and community involvement: A case study. (Doctoral dissertation, Liberty University, Lynchburg). Retrieved from: https://core.ac.uk/download/pdf/58825163.pdf

Çelenk, S. (2003). Okul-aile işbirliği ile okuduğunu anlama arasındaki ilişki. Hacettepe Üniversitesi Ĕ̆itim Fakültesi Dergisi, 24, 3-39.

Dam, H. (2008). Öğrencinin okul başarısında aile faktörü. Hitit Üniversitesi İlahiyat Fakültesi Dergisi, 7(14), 75-99. 
Dearing, E., Kreider, H., Simpkins, S., and Weiss, H. B. (2006). Family involvement in school and low-income children's literacy: Longitudinal associations between and within families. Journal of Educational Psychology, 98, 653-664.

Demirtaş, M. (2019). Suriyelilerin Türkiye'ye göç süreci ve ilişkiler aği: Ulubey Mahallesi (Yüksek Lisans Tezi, Hacettepe Üniversitesi, Ankara). Erişim adresi: https://tez.yok.gov.tr/UlusalTezMerkezi/tezSorgu SonucYeni.jsp

Erdoğan, Ç. ve Demirkasımoğlu, N. (2010). Ailelerin eğitim sürecine katıl1mina ilişkin öğretmen ve yönetici görüşleri. Kuram ve Uygulamada Eğitim Yönetimi [Educational Administration: Theory and Practice], 16(3), 399-431.

Erkan, S., Uludağ, G. ve Dereli, F. (2016). Okul öncesi öğretmenleri, okul yöneticileri ve ebeveynlerin aile katılımına ilişkin algılarının incelenmesi. Ahi Evran Üniversitesi Kırşehir Ĕ̆itim Fakültesi Dergisi, 17(1), 221-240.

Epstein, J. L. (2002). School, family, and community partnerships. California: Corwin Press Inc.

Gliner, J.A., and Morgan, G.A. and Leech, N.L. (2015). Research methods in applied settings: an integrated approach to design and analysis. (S. Turan, Çev.) Ankara: Nobel.

Hill, N. E., and Taylor, L. C. (2004). Parental school involvement and children's academic achievement: Pragmatics and issues. Current Directions in Psychological Science, 13, 161-164.

Hoover-Dempsey, K. V., Battiato, A. C., Walker, J. M., Reed, R. P., DeJong, J. M., and Jones, K. P. (2001). Parental involvement in homework. Educational Psychologist, 36, 195-209.

Johnson, S. B., Avrevalo, J., Cates, C. B., Weisleder, A., Dreyer, B. P., Mendelsohn, A. L. (2016). Perception about parental engagement among hispanic immigrant mothers of first graders from low-income back grounds. Early Childhood Education, 44(1), 445-4452.

Jung, E., Zhang, Y. (2016). Parental involvement, children's aspirations, and achievement in new immigrant families. Journal Of Education Research, 109(4), 333-350. 
Orçan Kaçan, M., Kimzan, İ., Güler Yıldız, T. ve Çağdaş, A. (2019). Öğretmen ve ebeveynlerin aile katılımını etkileyen etmenlere yönelik görüşlerinin incelenmesi. Eğitim Kuram ve Uygulama Araştırmaları Dergisi 5(3), 370-381

Keçeli Kayıslı, B. (2008). Akademik başarının arttırılmasında aile katılımı. Ankara Üniversitesi Ĕ̆itim Bilimleri Fakültesi Özel Eğitim Dergisi, 9(1), 69-83.

Lahaie, C. (2008). School readiness of children of immigrants: does parental involvement play a role. Social Science Quarterly, 89(3), 685-704.

Mafa, O. ve Makuba, E. (2013). The involvement of parents in the education of their children in Zimbabwe's rural primary schools: The case of Matabeleland north province, IOSR Journal of Research and Method in Education, 1(3), 37-43.

Moinolnolki, N., and Han, M. (2017). No child left behind: What about refugees? Childhood Education, 93(1), 3-9.

Mülteciler Derneği, Türkiye'deki Suriyeli Sayısı Eylül 2020, 29.09.2020 tarihinde https://multeciler.org.tr/turkiyedeki-suriyeli-sayisi/ adresinden ulaşılmıştır.

Özmen, A. E. (2018). Aile parçalanmasının çocuğun okul başarısına etkisi: Trabzon örneği. Karadeniz Araştırmaları Enstitüsü Dergisi, 4(5), 167225.

Rogers, M., Theule, J., Ryan, B., Adams, G. and Keating, L. (2009). Parental involvement and children's school achievement evidence for mediating processes. Canadian Journal of School Psychology, 24(1), 34-57.

Ryan, B. A., and Adams, G. R. (1999). How do families affect children's success in school? Education Quarterly Review, 6, 30-43.

Seginer, R. (2006). Parents' educational involvement: A developmental ecology perspective. Parenting: Science and Practice, 6(1), 1-48.

Shannon, S. M. (1996). Minority parental involvement: A mexican mother's experience and a teacher's interpretation. Education and Urban Society, 29, 71-84.

Simon B (2004). High school outreach and family involvement. J. Social Psychol. of Education, 7, 185-209. 
Şeker, M. (2009). Illköğretim 5. sinıföğrencilerinin performans görevlerindeki başarıları ile ailelerin eğitim-öğretim çalışmalarına katılım düzeyleri arasındaki ilişkinin belirlenmesi (Yüksek Lisans Tezi, Çukurova Üniversitesi, Adana). Erişim adresi: https://tez.yok.gov.tr/UlusalTezMerkezi/tezSorguSonucYeni.jsp Taşkaya, S. M. (2016). Anadili Türkçe Olmayanlara Okuma Yazma Öğretimi. F. Susar Kırmızı ve E. Ünal (Ed.), İlk okuma yazma öğretimi içinde (s.199-223). Ankara: Anı Yayıncilik.

Taylor, Z. E., Larsen-Rife, D., Conger, R. D., and Widaman, K. F. (2012). Familism, inter-parental conflict, and parenting in Mexican-origin families: A culturalcontextual framework. Journal of Marriage and $\mathrm{Fa}$ mily, 74(2), 312-327.

Tebben, C. (2017). Immigrant parental involvement in student academics. Emprowing Research for Educators,1(1), 6-19.

Tümkaya, S. (2017). Velilerin okulda eğitime katılım türlerinin bazı değişkenlere göre incelenmesi. Ç.Ü. Sosyal Bilimler Enstitüsü Dergisi, 26(2), 83-98.

Tümkaya, S. ve Çopur, E. (2020). Suriyeli ailelerin aile katılımına ilişkin öğretmen görüşleri. Ç.Ü. Sosyal Bilimler Enstitüsü Dergisi, 29(3), 368386.

UNHCR BM Mülteci Örgütü, Türkiye İstatistikleri, 29.09.2020 tarihinde https://www.unhcr.org/tr/unhcr-turkiye-istatistikleri adresinden ulaşılmıştır.

Yıldırım, A. ve Şimşek, H. (2016). Sosyal Bilimlerde Nitel Araştırma Yöntemleri. Ankara: Seçkin Yayıncllı.

\section{Kaynakça Bilgisi / Citation Information}

Tümkaya, S. ve Çopur, E. (2021). Suriyeli ebeveynlerin ilkokulda aile katılımına ilişkin görüşlerinin incelenmesi. OPUS-Uluslararası Toplum Araştırmaları Dergisi, 18(39), 348-381. DOI: 10.26466/opus.838731. 